\title{
Analysis of water flow velocity criteria for the selection of copper pipes on the example of production buildings
}

\author{
Alina Żabnieńska-Góra ${ }^{1, *}$, and Edyta Dudkiewicz ${ }^{1}$ \\ ${ }^{1}$ Wrocław University of Science and Technology, Faculty of Environmental Engineering, \\ Wybrzeże Wyspiańskiego 27, 50-370 Wroclaw, Poland
}

\begin{abstract}
The article presents different aspects of application of copper pipes in water supply system, which have importance on properly work of installation and people health safety. The article analyses the water flow velocity criteria and their influence on the operation of the installation. It is particularly dangerous for copper pipes to exceed the permissible water flow velocity, as this results in corrosive processes. It is also not recommended that the flow velocity be too low, as it affects the development of biofilm and multiplication of bacteria.
\end{abstract}

\section{Introduction}

According to the European Copper Institute $80 \%$ of copper extracted so far is still in use or is intended for reprocessing. The possibility of obtaining copper from secondary raw materials, without any loss in its quality, is a big advantage. Today $40 \%$ of Europe's demand for copper is met by copper obtained from secondary raw materials, which is used even in modern equipment. In generally copper pipes are more expensive than steel and plastic ones [1]. However owing to resistance to corrosion, their appropriate influence on water quality and ease of installation, copper and copper alloys are used in water installation $[1,2]$. The use of copper pipes in drinking water installations reduces the occurrence of biofilm and bacterial proliferation. However, in order for the copper water supply system to work properly, it is necessary to ensure proper working conditions [3].

On the properly working of copper water installation have impact the factors:

- quality of water delivered to water supply systems [2],

- temperature of water [4],

- $\quad$ kind of pipe insulation materials [1],

- hydraulic of conditions of work [2, 5],

- conditions of exploitation of water installation [2].

\footnotetext{
* Corresponding author: alina.zabnienska@pwr.edu.pl
} 


\section{Water corrosivity criteria for copper}

According to the Regulation of the Minister of Infrastructure and Development [6] "products used in water supply systems should be selected taking into account the corrosivity of water, so that its quality and durability do not deteriorate and such effects do not cause mutual influence materials from which these products were made". The Regulation of the Minister of Health [7] in Appendix 3 specifies the indicators (chlorides, sulphates, conductivity, $\mathrm{pH}$ ) that should be taken into account when assessing the corrosive properties of water. This is particularly important when designing copper pipe systems. Water with inadequate chemical parameters in the copper installation may cause corrosion. It is precisely for reasons of water quality that the use of copper pipes for water installations is not recommended in some regions of Poland. The literature, e.g. [2], states that $10 \%$ of tap water has a composition that is not conducive to the formation of protective layers on the internal surfaces of copper pipes.

Limiting values determining the corrosive risk of metal are specified in the standard PNEN 12502:2006 [8]. The standard [8] refers to the guidelines for testing the possibility of corrosion in water distribution and storage installations [10]. The requirements for tap water for copper feed systems refer to $\mathrm{pH}$, nitrate ion content $\left(\mathrm{C}_{\mathrm{NO}_{3}^{-}}\right)$, sulphate ion $\left(\mathrm{C}_{\mathrm{SO}_{4}^{2-}}\right)$ and general alkalinity $\left(\mathrm{Z}_{\text {ogóna }}\right)$. The numerical values of the indicators of the above parameters are presented below:

$$
\begin{aligned}
& \mathrm{pH}>7 \\
& C_{\mathrm{NO}_{3}^{-}}<30 \mathrm{mg} / \mathrm{l} \\
& \frac{Z_{\text {ogólna }}}{C_{\mathrm{SO}_{4}^{2-}}}>2
\end{aligned}
$$

General corrosion can occur in copper water installations if they are not installed correctly. This corrosion may be caused by low $\mathrm{pH}$ value of water (below 6.5), presence of sulphate, chloride, nitrate ions, high content of carbon dioxide. In addition, e.g. in water treatment processes, depriving water of organic compounds, which are inhibitors of copper corrosion, also leads to corrosion of pipes. Soft water does not have carbonate hardness (which regulates the level of acidity and alkalinity of the water). This leaves carbon dioxide in the water, which transforms into unstable carbonic acid. When water flows through the water supply system, copper pipes corrode and copper flows into drinking water, which, in too high a concentration, is considered a toxic element. Such water may acquire a specific smell and taste unpleasant for the users [2]. According to the Regulation of the Minister of Health [7] the content of copper per liter of drinking water should not exceed $2 \mathrm{mg}$.

Pitting corrosion is when perforation of the pipe wall occurs as a result of particles and deposits on the inside surfaces of the pipes or, for example, as a result of leakage of soft soldering flux on the inside surface of the pipe (especially when the flux contains chloride ions that are corrosively hazardous). The corrosion of copper pitting takes place in different ways for cold and hot water. In cold water, corrosive risks are only present in unfavorable operating conditions and assembly installation errors. In hot water, the components of water influence the corrosion process of copper in various ways [4]. The phenomenon of selective corrosion may occur when the installation includes elements (e.g. valves) made of copper alloys such as brass (brass resistant to dezincification must be used).

The simultaneous action of corrosion and a turbulent stream of water, which locally destroys the oxide layer (the passive layer, which is the protective layer of the metal) causes erosion corrosion. In this case, the turbulent flow of water results not only from exceeding the permissible speeds specified for copper pipes, but also from any flow disturbances where 
the speed increases locally and turbulence occurs. Such conditions arise in the area of pipe cross-sectional changes, around soldering overhangs, and even in the areas of water flow direction changes (elbows, long radius elbow).

In order to prevent erosive corrosion of copper pipes, it is important to follow the recommended maximum flow rates for copper pipe installations at the design stage.

\section{Water flow velocity criteria}

One of the basic conditions of properly working is to ensure that the water flow velocity is adequate. This parameter is relevant for dimensioning the water supply system including the diameter selection of the water pipes. Criterion of the flow velocity of the water varies depending on the manufacturers guidelines, the material used and the law.

Ensuring the water velocity in the installation in accordance with the recommendations for pipes is important. Because the speed of water affects:

- the degree of corrosion of the pipe,

- the noise level of the system,

- hydraulic impacts,

- linear and local pressure losses in the system,

- the development of biofilms, which, in addition to the temperature and stagnation of the water, are essential to prevent and combat the proliferation of Legionella bacteria [9].

The common relations stated in the standard PN-92/B-01706 [10] provide the basis of designing water supply system in buildings. However, although according to Polish Committee for Standardization this standard bears the status of "withdrawn without replacement", it is cited in the amendment of the Regulation of the Minister of Infrastructure and Development [6] as concerns, among other things, the general rules of sizing the water supply conduits and determining the design water flow rates in residential buildings, office buildings, hotels and department stores.

Admissible maximum velocities of water which are decisive criterion in selecting the diameters of piping are, according to PN [10], as follows:

- up to $1.5 \mathrm{~m} / \mathrm{s}$ in connections from riser to draw-off points and in risers of water supply system,

- up to $1 \mathrm{~m} / \mathrm{s}$ in main distribution lines and home service pipes.

Manufacturers of plastic pipes specify the following admissible velocities:

- for risers and service lines to draw-off points - up to $2.5 \mathrm{~m} / \mathrm{s}$,

- for main distribution lines - up to $2 \mathrm{~m} / \mathrm{s}$,

- for water supply service pipes - up to $1.8 \mathrm{~m} / \mathrm{s}$.

In accordance with PN-EN 806-3:2006 [11], the maximum speed in a single connections from riser to draw-off points can be $4 \mathrm{~m} / \mathrm{s}$, while in other installation pipes it can be up to $2 \mathrm{~m} / \mathrm{s}$. Then the requirements on admissible velocities in water system pipes acc. to DIN [12], depending on the duration of maximum flow rate and local resistances of the fixtures on the plot, are specified in Table 1.

For the reason of erosion-corrosion in the copper water installations the water flow velocity should not exceed $1 \mathrm{~m} / \mathrm{s}$ in horizontal conduits and $2 \mathrm{~m} / \mathrm{s}$ in connections $[2,3,5]$. It is recommended to use long radius elbow instead of bends, which are less sensitive to scratches and destruction of the oxide layer due to pollution carried in tap water. At the beginning of the copper installation (behind the water meter set), a mechanical filter with a retention capacity of particles larger than $80 \mu \mathrm{m}$ should be installed [3].

For the reason of corrosion steel pipes are using primarily in installation of cold water or to deliver water to tank water. In the steel water installations the water flow velocity should not exceed $1 \mathrm{~m} / \mathrm{s}$ in horizontal conduits and 1,5 m/s in connections and in risers $[10,13]$. 
Table 1. Water flow velocity acc. DIN 1988-300:2012-05 [12]

\begin{tabular}{|l|c|c|}
\hline \multirow{2}{*}{ Type of water-pipe } & \multicolumn{2}{|c|}{ Water velocity [m/s] } \\
\cline { 2 - 3 } & $\begin{array}{l}\text { Duration of calculated } \\
\text { flow water <15 min }\end{array}$ & $\begin{array}{l}\text { Duration of calculated } \\
\text { flow water } \geq 15 \text { min }\end{array}$ \\
\hline Water supply connection & 2.0 & 2.0 \\
\hline $\begin{array}{l}\text { Sections in the installation with elements } \\
\text { with resistance coefficient } \zeta<2.5\end{array}$ & 5.0 & 2.0 \\
\hline $\begin{array}{l}\text { Sections in the installation with elements } \\
\text { with resistance coefficient } \zeta \geq 2.5\end{array}$ & 2.5 & 2.0 \\
\hline
\end{tabular}

Most design guidelines and standard [10] specify the criteria for water velocity by distribution line and riser, while DIN [12] takes into account the flow time and local losses of the installation. In single-storey buildings without traditional water risers, the water supply system has main distribution lines and connections from main distribution lines to draw-off points. In this section, the speed criteria should be used when selecting the pipe diameters according to the recommendations described above.

A higher water velocity generates higher pressure losses. The coefficient of unit pressure losses depends on the value of the absolute roughness coefficient $\mathrm{k}$. It is different for different materials and the smaller its value (i.e. the surface is smoother), the lower the water flow pressure losses and the lower the possibility of sludge formation and material destruction.

Over time, the pipes are inlayed by the deposition of chemical compounds that precipitate from the water or are the result of corrosion of the pipe material (chemical deposits and hydrobiological growth - biofilm). This increases the roughness of the inner pipe walls and at the same time reduces the cross-sectional area of the pipes. An increase in hydraulic head losses, i.e. a decrease in the flow rate (hydraulic efficiency) of water pipes, is highly undesirable $[14,15]$. The roughness coefficient for copper pipes is $\mathrm{k}=0.0015 \mathrm{~mm}$ [15].

\section{The importance of biofilm development}

Water supply systems can be a breeding ground for pathogenic bacteria and parasites. Particular attention has been paid in recent years to the risks associated with the operation of hot water systems where conditions are favorable to the development of Legionella bacteria. The temperature range of $35-46^{\circ} \mathrm{C}$, long stagnation time of water and the presence of biofilm and sediments on surfaces in contact with water facilitate the multiplication of Legionella bacteria in installations [2,9]. The type of installation material and associated characteristics such as corrosion resistance, surface roughness and chemical composition have a significant influence on the development of the biofilm. On the basis of numerous studies [2,9], the inhibitory effect of copper ions on the multiplication of Legionella bacteria is found in copper installations.

The impact of speed is also very important. On the one hand, high velocity is desirable due to shear forces that reduce the upper layers of the biofilm, and on the other hand, it promotes the formation of biofilm, as it ensures the supply of nutrients [9]. Too low a water velocity promotes the development of a biofilm resistant to adverse environmental conditions, in which microorganisms multiply. Hot water and circulation water pipes in which there is a constant flow of water are not exposed to stagnation of water, as are cold water pipes. From a legionnaire protection point of view, it is recommended to ensure a maximum speed of $1-2 \mathrm{~m} / \mathrm{s}$ in copper cold and hot water pipes without circulation. It should be added that thermal disinfection, as recommended by the regulations [6], is carried out without any negative effects on the durability of the copper installation [3]. 


\section{Analysis of water speed measurements in halls}

Measurements of the hot water flow velocity were carried out in two production halls with different water load pattern. Water flow velocity was measured with a portable ultrasonic flow meter (PORTAFLOW C) on the pipe delivering water to hot water tank. Data was archived every 10 seconds. Halls are localized in Bolesławiec and in Wrocław. These are objects with different degrees of soiling work and other sanitary equipment. In this type of buildings, water is distributed horizontally. Table 2 summarises the characteristics of the production halls where the measurements were made.

Table 2. Characteristics of the production halls

\begin{tabular}{|c|c|c|}
\hline Location & Bolesławiec & Wrocław \\
\hline Number of work shift & 3 & 3 \\
\hline Number of people on shift & $\begin{array}{l}\text { I }-145 \\
\text { II }-65 \\
\text { III }-25 \\
\Sigma=235\end{array}$ & $\begin{array}{l}\text { I }-300 \\
\text { II }-250 \\
\frac{\text { III }-200}{\Sigma=750}\end{array}$ \\
\hline Number of working days per week & 5 & 6 \\
\hline Degrees of soiling work & high soiling & low soiling \\
\hline \multirow{2}{*}{$\begin{array}{l}\text { Sanitary equipment (delivered hot water): } \\
\text { Shower } \\
\text { Sink }\end{array}$} & Yes & No \\
\hline & Yes & Yes \\
\hline Average daily hot water consumption $\left[\mathrm{m}^{3}\right]$ & 16 & 20 \\
\hline $\begin{array}{l}\text { Average daily hot water consumption per person } \\
\text { [1/person] }\end{array}$ & 68 & 26 \\
\hline Average weekly hot water consumption $\left[\mathrm{m}^{3}\right]$ & 104 & 133 \\
\hline
\end{tabular}

The results of the research of the water flow velocity during one week in a production halls are presented on Fig. 1 (hall in Bolesławiec) and Fig. 2 (hall in Wrocław).

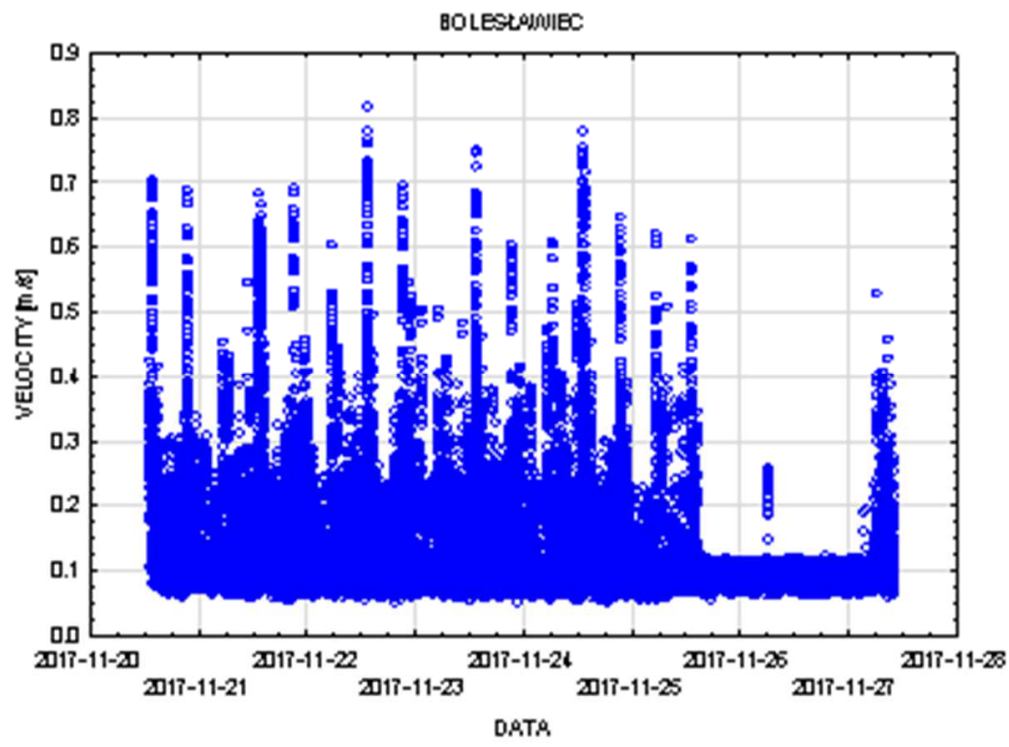

Fig. 1. Distribution of water velocity in production hall with high soiling in Bolesławiec

Table 3 presents the average, minimum and maximum values of the measured value of water flow velocity and standard deviation. 
The both diagrams show that water velocities are below value $1 \mathrm{~m} / \mathrm{s}$ recommended for copper pipes. Considerably larger water velocity is observed after the shifts on weekdays, than during weekend. In the hall in Bolesławiec, a marked increase in speed was observed after each finished shift. In Bolesławiec (fig. 1) water velocity is not higher than $0.82 \mathrm{~m} / \mathrm{s}$ on weekdays while during the weekend average velocity $0.27 \mathrm{~m} / \mathrm{s}$. Between shifts water velocity is rather low, about $0.3 \mathrm{~m} / \mathrm{s}$. In Wrocław (fig. 2) water velocity is not higher than $0.55 \mathrm{~m} / \mathrm{s}$ on weekdays and $0.15 \mathrm{~m} / \mathrm{s}$ during a weekend when fewer people are at work. These velocities show that the system is oversized in this hall.

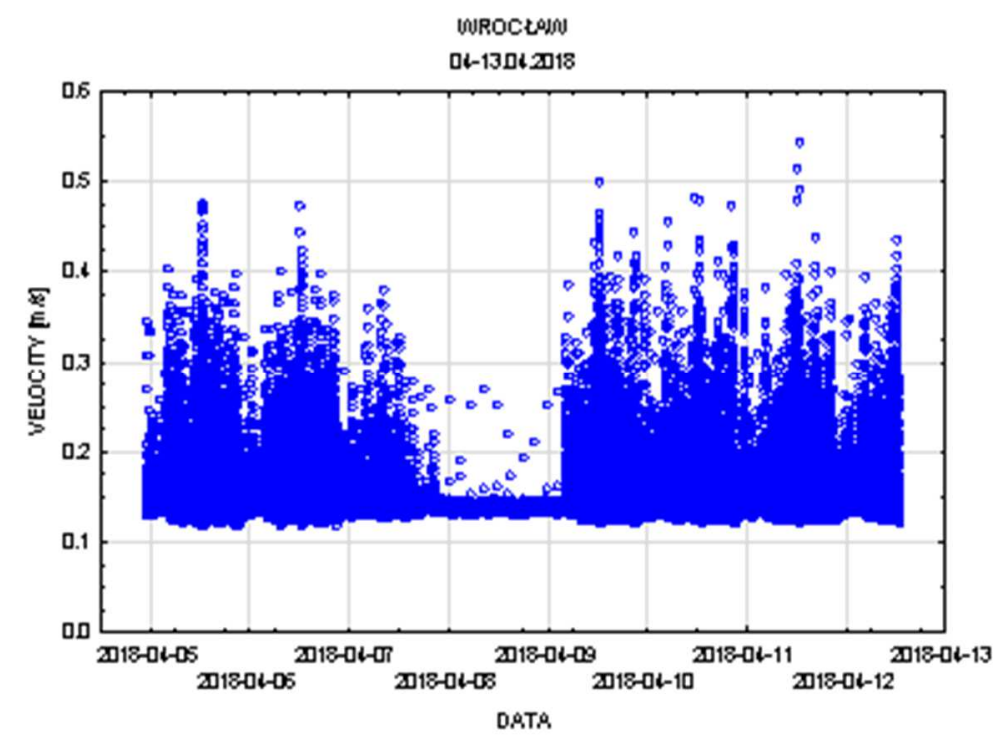

Fig. 2. Distribution of water velocity in production hall with low soiling in Wrocław

Table 3. Summary of flow velocity

\begin{tabular}{|c|c|c|c|c|c|}
\hline \multicolumn{2}{|l|}{ Location } & $\begin{array}{c}\text { Average value } \\
\mathrm{m} / \mathrm{s}\end{array}$ & $\begin{array}{c}\text { Min. value } \\
\mathrm{m} / \mathrm{s}\end{array}$ & $\begin{array}{c}\text { Max. value } \\
\mathrm{m} / \mathrm{s}\end{array}$ & $\begin{array}{c}\text { Standard } \\
\text { deviation }\end{array}$ \\
\hline \multirow{2}{*}{ Bolesławiec } & working days & 0.128 & 0.000 & 0.816 & 0.083 \\
\cline { 2 - 6 } & weekend & 0.095 & 0.055 & 0.618 & 0.038 \\
\hline \multirow{2}{*}{ Wrocław } & working days & 0.155 & 0.117 & 0.542 & 0.042 \\
\cline { 2 - 6 } & weekend & 0.139 & 0.125 & 0.378 & 0.014 \\
\hline
\end{tabular}

\section{Conclusion}

The water flow rates in the system are very important for many factors. The water velocity criteria are given mainly depending on the installation material. In addition, most design guidelines and standard [10] specify the criteria for water flow velocity, broken down into distribution pipes, risers and service lines to draw-off points. The approval of appropriate water velocity criteria is the first step to ensure the correct operation of the system. However, the proper construction, commissioning and maintenance of the water supply system will have an impact on water quality and human health.

Taking into account all water flow velocity criteria and their influence on the operation of the installation, speed criteria $(1 \mathrm{~m} / \mathrm{s}$ in main distribution lines and $2 \mathrm{~m} / \mathrm{s}$ in connections from riser to draw-off points) should be used for selecting the diameter of copper pipes.

The results of measurements in production halls show that the water flow velocities are below than recommended value $1 \mathrm{~m} / \mathrm{s}$ and are at weekends are much lower than assumed. 
The average water flow velocities are in the range not recommended for water supply systems. These outcomes of velocities show that the water system is oversized in Wrocław. This is due to the method of determining the water flow rate. There is no clear method to calculate the water flow in the production halls.

Low water velocities in the period between work shifts and periods of water stagnation in the halls make it possible to conclude that, from the point of view of microbiological contamination, copper pipes are an appropriate solution in this type facilities, as it has an inhibitory effect on the proliferation of Legionella bacteria.

The participation in the conference was co-financed by the Faculty of Environmental Engineering, Wroclaw University of Science and Technology, Poland (award by Ministry of Science and Higher Education in years 2017-2018 No. 0401/0007/17).

\section{References}

1. Dasdemir A., Ural T., Ertürk M., Keçebas A.: Optimal economic thickness of pipe insulation considering different pipe materials for HVAC pipe applications, Applied Thermal Engineering, 121, pp 242-254, (2017)

2. Toczyłowska B.: The impact of copper water pipelines on water quality, Polish Copper Promotion Center, Wrocław, Poland, (2004)

3. Technical requirements COBRTI INSTAL, Notebook 10. Guidelines for the design and use of copper pipe installations. Information Center "Installation technique in construction, (2003)

4. Falewicz P., Drela I., Kuczkowska S.: Aggressiveness of corrosive waters, Protection against corrosion, Poland, 4-5, pp 187-191, (2008)

5. Dudkiewicz E., Żabnieńska-Góra A.: The importance of flow-rate to working of hot and cold water copper installation, Rynek Instalacyjny, 11, pp 41-43, (2016)

6. Regulation of the Minister of Infrastructure of 12 April 2002 on the technical conditions that buildings and their location, 75 pos. 690 (with z later changes)

7. Regulation of the Minister of Health of 13 November 2015 on the quality of water intended for human consumption (dz. U, poz. 1989)

8. PN-EN 12502:2006 Protection of metallic materials against corrosion - Guidelines for assessing the risk of corrosion in water distribution and storage systems - Part 1: General provisions; Part 2: Factors affecting copper and copper alloys.

9. Toczyłowska B.: The role of biofilm in preventing and fighting with legionella bacteria in water supply system, Water supply and sewage installations - design, construction, operation (Seidel-Przywecki Warszawa 2015)

10. PN-92/B-01706 Water supply installations - Requirements in the design

11. PN-EN 806-3:2006 Specifications for installations inside buildings conveying water for human consumption - Part 3: Pipe sizing - Simplified method

12. DIN 1988-300:2012-05 Technische Regel für Trinkwasser-Installationen (TRWI) Ermittlung der Rohrdurchmesser Technische Regel des DVGW.

13. Górecki A.: Corrosiveness of tap water and installation material, Rynek Instalacyjny, 9, pp 62-67, (2011)

14. Kotowski, A.: Hydraulic Analysis of Phenomena Reducing Pipeline Flowability. Ochrona Środowiska, 32, 1, pp. 27-32, (2010)

15. Stefański W.: The influence of increasing the roughness and reducing the pipe diameter on hydraulic resistance, Instal, 9, pp 66-74, (2006) 